\section{Cientific Paper}

\section{Abstract}

In the search of alternative methods for disease control in plants, the essential oil and vegetal extracts of Salvia officinalis appear as an option. In this study, it was evaluated in vitro and in vivo the effect of the essential oil and plant extracts (hydroethanol, ethanol and infusion) of Salvia officinalis with potential antifungal activity against the pathogen Sclerotinia sclerotiorum (Lib.) de Bary. The essential oil was tested in the concentrations of $0.01,0.05,0.1,0.15$ and $0.2 \%$, and the extracts in the concentrations of 5,10,15 and 20\%. In the in vitro tests, the essential oil inhibited the mycelial growth of the pathogen starting from the concentration of $0.15 \%$. In vivo tests were performed in the concentration of $0.20 \%$. The same did not occur with any of the extracts tested, having no inhibition of fungal growth. These results indicate the potential of salvia oil for the control of sclerotinia rot in lettuce.

Key words: Alternative control of disease; esclerotinia rot; antifungal effect.

\section{Utilização de óleo essencial e extratos vegetais de Salvia officinalis L. no controle de podridão de Sclerotinia em alface}

\author{
Marcia Regina Pansera ${ }^{1}$ \\ Manuela Pauletti ${ }^{2}$ \\ Caroline Perin Fedrig ${ }^{2}$ \\ Valdirene Camatti Sartori ${ }^{3}$ \\ Rute Teresinha da Silva Ribeiro ${ }^{4}$
} $g^{2}$

.

(1)

(1)


inhibió el crecimiento micelial del patógeno a partir de la concentración de 0,15\%. Los ensayos in vivo se realizaron a una concentración de 0,20 \%. El mismo no ha ocurrido con cualquiera de los extractos ensayados, donde no se ha observado inhibición del crecimiento fúngico. Estos resultados indican el potencial del aceite de salvia para el control de la podredumbre por Sclerotinia en la lechuga.

Palabras clave: control alternativo de enfermedad; podredumbre por Sclerotinia; efecto antifúngico.

\section{Introduction}

The lettuce (Lactuca sativa L.) is among the ten most appreciated vegetables in Brazil, in the in natura form (RODRIGUES, 2007). However, this crop presents several diseases, which, among them stand out the white mold caused by the fungi Sclerotinia sclerotiorum (Lib.) De Bary, a pathogen that survives in the soil and can infect the plant in any development stage (KUHN, 2006). To control this disease, researches have been developed aiming the use of alternative methods, replacing the traditional fungicides (SCHWAN-ESTRADA, 2003). Several studies have demonstrated the effect of metabolites extracted from plants, such as essential oils and vegetal extracts, which act as natural fungicides, inhibiting the fungi activity (ATTI-SANTOS, 2010). Therefore, this study had as objective to assess the essential oil and vegetal extract effect (hydroethanol, ethanol and infusion) of the Salvia (Salvia officinalis) with potential antifungal activity against the pathogen Sclerotinia sclerotiorum (Lib.) de Bary.

\section{Material and Methods}

This study was done in the Control Laboratory of Plant Diseases of the Institute of Biotechnology of the Universidade de Caxias do Sul/RS. The microorganism Sclerotinia sclerotiorum (A 69/11) was isolated from the lettuce with white mold, originating from Farroupilha / RS.

The Salvia leaves (Salvia officinalis) were collect in the municipality of Caxias do Sul (S / $29^{\circ} 09^{\prime} 78.0^{\prime \prime}$ e $\left.W / 51^{\circ} 08^{\prime} 65.9^{\prime \prime}\right)$. The essential oil extraction of the fresh plant was done through hydrodistillation in Clevenger instrument during one hour. The chromatographic analysis was done in GC (HP 6890) and GC/MS (HP 6890/MSD5973, equipped with Wiley espectroteca).

For the in vivo test were used lettuce seeds of the variety Crisp Grand Rapids -TBR/ISLA PAK/ Brasil. The seeds did not receive any type of treatment before the sowing.

Three different types of extract were done in this study: hydroethanol, ethanol and infusion.
Extract by Infusion: Fresh leaves of the plant were boiled with distilled water during $20 \mathrm{~min}$. The resulting homogenates of the extract were filtered in filter paper. Hydroethanol Extract: The hydroethanol extract was obtained through the maceration of dried and grounded plants with the hydroethanol solution by turbo extraction during eight minutes, with interval of three minutes between the times. This extract was prepared at $20 \%$, that is, $20 \mathrm{~g}$ of the grounded and dried plant was macerated with $100 \mathrm{~mL}$ of hydroethanol extract at $70 \%(\mathrm{v} / \mathrm{v})$. The homogenates were filtered with gauze. This was placed to rest at $45^{\circ} \mathrm{C}$, for 12 hours for the evaporation of the ethanol to avoid the interference of the action of these in the experiments. Then, the extract was completed with distilled water until obtaining the initial volume, in this way the extract was filtered with filter paper and cellulose membrane of $0.2 \mu \mathrm{m}$ of porosity. Ethanol Extract: The fresh plant $(60 \mathrm{~g})$ remained in an amber vial with $200 \mathrm{~mL}$ of PA ethanol for 15 days. After this period, the resulting liquid was filtered and taken to the rotary evaporator for the evaporation of the solvent. Evaluation in vitro of the essential oil biological activity and of the vegetal extract on the mycelial growth of S. sclerotiorum: The autoclaved essential oil resulted in the concentrations $0.01 ; 0.05 ; 0.1 ; 0.15$ and $0.20 \%$. For the extract, the concentrations were of 5,10,15 and $20 \%$. The PDA medium was plated, and a disk ( $0.5 \mathrm{~cm}$ of diameter) of colonized agar of $S$. sclerotiorum was transferred to the center of each plate. The control treatment contained only the PDA medium. The plates were incubated in BOD at $25^{\circ} \mathrm{C}$ for 7 days. The assessments were made in the $3^{\text {rd }}, 7^{\text {th }}$ and $14^{\text {th }}$ days of incubation through the measures of the fungi growth colony diameters.

Assessment in vivo of the essential oil biological activity on the mycelial growth of $S$. sclerotiorum in the lettuce: For the evaluation of the potential of $S$. sclerotiorum biocontrol in lettuce, the experiments were made in greenhouse installations of the Universidade de Caxias do Sul Biotechnology Institute. These tests were made only for the best results of the concentrations in vitro. For the preparation of the inoculum of S. Sclerotiorum, disks of PDA medium containing mycelia of the fungi 


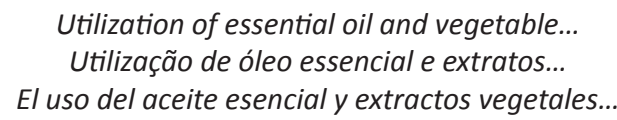

were directly placed in the autoclaved substrate with pieces of lettuce leaves and were moistened with distilled water. During this period (15 days), the fungi colonized the whole substrate and formed a great quantity of sclerotia. The treatments were disposed in a completely randomized design with three repetitions of 50 plants each. The lettuce seedlings, with 10 days old were transplanted to the colonized substrate with the pathogen. Next, the following treatments were done: Treatment A: soon after the transplantation the oil was applied in the concentration of $0.20 \%$. These applications were made once per week until completing 30 days. Control 1: Soil free of the pathogen. Control 2: Soil with the pathogen. Data analysis: The results were analyzed through the variance analysis One-Way ANOVA, with the post-test Tukey for one $\mathrm{p}<0.05$, using the computational program SPSS 17.0.

\section{Results and Discussion}

The essential oil yield of the Salvia officinalis was of $1.1 \%$. It had as main components the a-thujone, caryophyllene, 1.8-cineole, a-humulene and camphor. DUKE et al. (2002) and POVH, (2006) mention in their studies about the $S$. officinalis essential oil that the compounds found are biologically active and have toxic and pharmacological actions.

The data presented in Table 1 shows that there was a significant difference between the tested essential oil and the control, during the 14 days of experiment, but there was no mycelial growth of the plant pathogenic fungus at the concentration of $0.20 \%$.

In the same way, DALAMARE et al. (2007) and POZZO et al. (2011) observed salvia essential oil activity on some isolates of Staphylococcus spp. In a study made by PEREIRA et al. (2006) the antimicrobial activity of the oil extracted from Salvia officinalis L. was assessed and the responses pointed out inhibition on the microorganisms development such as the E. coli, Klebsiella pneumoniae, Proteus mirabilis, Morganella morganii, Enterobacter aerogenes and Klebsiella oxytoca.

According MAYAUD et al. (2008), the essential oils of oregano, salvia and thyme have significant antimicrobial potential against the Grampositive and Gram-negative bacteria and fungi.

Likewise, ASTOLFI et al. (2007) showed inhibitory effect of this essential oil on the Grampositive bacteria development (Staphylococcus aureus and S. epidermidis) and Gram-negative (Citrobacter freundii and Shigella flexneri) demonstrating its efficiency as antimicrobial activity agent. In a similar study, MARQUES et al. (2003) observed the inhibition of $100 \%$ in the mycelial growth of C. gloeosporioides, however only until the fifth day, with reduction of the inhibition potential to $62.77 \%$ in the eighth day of treatment with the essential oil of Cymbopogom citratus.

According to SANTOS et al. (2009), the $S$. terebinthifolius was effective for the Botrytis spp., it was observed inhibition of the halo growth, in all the tested dilutions for all the assessed times, which is this case were of 24,48 and 72 hours. This author also reports that the same oil does not present fungicide effect against Colletotrichum spp. and Fusarium spp., however it may occur inhibition of the fungus growth using dilutions superior to $10 \%$ for the Colletotrichum spp. and inferior to $10 \%$ for the Fusarium spp. and Alternaria spp.

The data presented in Table 2 represent the Incidence Percentage of the disease in lettuce in the tested treatments. In relation to the treatment $\mathrm{A}$, preventive treatment, there was $20 \%$ of incidence of the disease in relation to the control 2 (soil with pathogens $-100 \%$ ). Now for the control 1, where the soil was free of pathogens, there was no incidence of the disease.

Table 1. in vitro effect of the Salvia officinalis essential oil on the development of the pathogen S. sclerotiorum at the $14^{\text {th }}$ day.

\begin{tabular}{cc}
\hline Essential oil concentration (\%) & $\begin{array}{c}\text { Salvia officinalis } \\
\text { (mycelial growth of the pathogen - mm) }\end{array}$ \\
\hline 0 & $91.76 \mathrm{aA}$ \\
0.01 & $89.85 \mathrm{aA}$ \\
0.10 & $90.16 \mathrm{aA}$ \\
0.15 & $83.39 \mathrm{aA}$ \\
0.20 & $0 \mathrm{~b} \mathrm{C}$ \\
\hline
\end{tabular}

Averages followed by the same letter, capital letter between species and lower case between concentrations do not differ, by the Tukey test at $5 \%$ of probability.

Applied Research \& Agrotecnology v6 n2 may/aug. (2013)

Print-ISSN 1983-6325 (On line) e-ISSN 1984-7548 
Pansera et al. (2013)

GARC and SIDDIQUI (1992) did studies with isolated substances of the basil essential oil (Ocimun sanctum) and evidenced fungistatic action in diverse fungi. The purified eugenol was tested in the dilution of 1:100 and 1:200, presenting strong action against the Absidia glauca, Alternaria alternata, Aspergillus niger, Colletotrichum capsici, Fusarium moniliforme and Rhizopus nodosus. SINGH et al. (1993) used basil aqueous extract in banana fruits to control the diseases caused by fungi of the genera Fusarium, Helminhosporium, Curvularia, Aspergillus and Trichoderma and obtained efficient results. WECKESSER et al. (2007), assessed extracts of different plants, including the S. officinalis on 29 aerobic, anaerobic and yeast bacteria, and verified important antimicrobial activity of the salvia.

SOUZA et al. (2005) related that the intensity of the essential oil biological activity depends of some chemical constituents, such as the citral, pinene, cineol, caryophyllene, elemene, furanodiene, limonene, eugenol and carvacrol, however it is important to comment that due the chemical composition complexity of a essential oil, it becomes difficult to relate the biological activity with the present substances. Generally, the action attributed to an isolated chemical compound may not be exact, due to the possible interactions that may happen between the oil compounds (APEL, 2001; SANTOS, 2006). In the present study, the reached results allow to suggest that the $S$. officinalis essential oils present fungitoxic effect on the pathogen $S$. sclerotiorum in the assessed conditions and also present potential use for the control of the rotting caused by this agent. The essential oils are complex mixtures, and because of this must be identified and tested separately, with the intention of elucidating the action of these compounds on the fungus behavior.

In relation to the tested vegetal extracts, they do not present control in relation to the fungus $S$. sclerotiorum as reported by the data in Table 3 . These

Table 2. Incidence (\%) of S. sclerotiorum in the lettuce after the application of the treatments (A) soon after the transplantation the oil was applied at the concentration of $0.20 \%$; (Control 1) Soil free of pathogens; (Control 2) Soil with pathogens.

\begin{tabular}{cccc}
\hline Plants and Treatments & $\begin{array}{c}\text { S. officinalis } \\
\text { (Treat. A) }\end{array}$ & $\begin{array}{c}\text { Soil free of the pathogen } \\
\text { (Control 1) }\end{array}$ & $\begin{array}{c}\text { Soil with the pathogen } \\
\text { (Control 2) }\end{array}$ \\
\hline $\begin{array}{c}\text { Incidence Percentage of the } \\
\text { disease }\end{array}$ & $20 \% \mathrm{~b}$ & $0 \mathrm{c}$ & $100 \%$ a \\
$\begin{array}{c}\text { Averages followed by the same letter, capitalletter between species and lower case between concentrations do not differ, by the Tukey test at } 5 \% \text { of probability. }\end{array}$
\end{tabular}

Table 3. in vitro effect of the different Salvia officinalis extracts on the development of the pathogen S. sclerotiorum at the $14^{\text {th }}$ day.

\begin{tabular}{ccc}
\hline Extracts types & Essential oil concentration (\%) & Mycelial growth (mm) \\
\hline & 0 & $91.76 \mathrm{a}$ \\
& 5 & $91.76 \mathrm{a}$ \\
Infusion & 10 & $91.76 \mathrm{a}$ \\
& 15 & $91.76 \mathrm{a}$ \\
& 20 & $91.76 \mathrm{a}$ \\
\hline Hydroethanol & 0 & $91.76 \mathrm{a}$ \\
& 5 & $90.15 \mathrm{a}$ \\
& 10 & $92.48 \mathrm{a}$ \\
& 15 & $90.31 \mathrm{a}$ \\
& 20 & $92.08 \mathrm{a}$ \\
\hline & 0 & $91.76 \mathrm{a}$ \\
& 5 & $91.76 \mathrm{a}$ \\
& 10 & $91.76 \mathrm{a}$ \\
& 15 & $91.76 \mathrm{a}$ \\
\end{tabular}

Averages followed by the same letter, capital letter between species and lower case between concentrations do not differ, by the Tukey test at $5 \%$ of probability. 


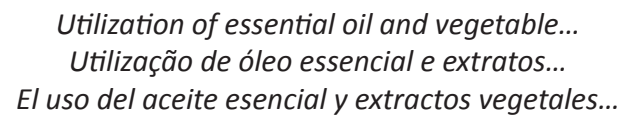

results can be attributed to a possible inadequacy of the used doses, suggesting that in future studies use increased doses.

Differently from our study, ITAKO et al. (2008) related that the Cymbopogom citratus extract at $10 \%$ completely inhibited the in vitro growth of several pathogens which cause roots rotting in bean plants. According to BORGES (2007), vegetal extracts are complex substances which can present more than one model and way of act. Many studies with vegetal extracts obtained from medicinal plants have indicated potential in control of plant diseases (BANÕS et al., 2003) both through direct fungitoxic action, inhibiting the mycelial growth and the spore germination, as through the induction of phytoalexins, indicating the presence of compounds of elicitor character (SCHWAN-ESTRADA et al., 2003). Another study that agrees with our results as for the inhibition of the pathogenic organism growth is the one from BORGES (2007), where inhibitory effect was detected of the urediniospores germination of Phakopsora pakhyrhizi, an etiologic agent of Asian soybean rust, with the use of salvia extract. The author verified that there was only 3.5\% of urediniospores germination with an average inhibition of $87.03 \%$ in relation to the water control. ROSAL et al. (2009) verified that the salvia aqueous extract can be used as an alternative for the control of Penicillium sp. and the study pointed out that with greater concentrations application, greater is efficiency on the pathogen control.

In relation to the mycelial growth inhibition and sclerotia production of S. sclerotiorum, there was alteration of the colony morphology and inhibition of the sclerotia formation at the concentration of $20 \%$ for the essential oil of Salvia officinalis. This can very useful for the inoculum reduction of the fungus in the subsequent plantings of vegetables in the same soil (RODRIGUES, 2007).

\section{Conclusion}

This study allowed evidencing the specificity of the Salvia officinalis essential oil activity on the isolated of S. sclerotiorum in relation to the control of the White Mold or Sclerotinia Rot. Additional studies approaching the synergism between the essential oils, majority fractions, antibacterial agents and antifungal are fundamental for the development of alternative products for the control of plant diseases.

\section{References}

ATTI-SANTOS, A.C.; ROSSATO, M.; SERAFINI, L.A.; BUENO, M.; CRIPPA, L.B.; SARTORI, V.; DELLACASSA, E.; MOYNA. P. Efeito fungicida dos óleos essenciais de Schinus molle L. e Schinus terebinthifolius Raddi, Anacardiaceae, do Rio Grande do Sul. Brazilian Journal of Pharmacognosy, v.20, p.154-159, 2010.

BANÕS, B.S. et al. Effects of chitosan and plant extracts on growth of Colletotrichum gloeosporioides, anthracnose levels and quality of papaya fruit. Crop Protection, v.22, n.9, p. 1087-1092, 2003.

BORGES, D.I. Óleos e extratos vegetais no controle da ferrugem asiática da soja (Glicine max L.).Universidade de Lavras. Dissertação (Mestrado em Fitopatologia)- UFLA. 2007. 63f.

DAL POZZO, M.; VIÉGAS, J.; SANTURIO, D.F.; ROSSATTO, L.; SOARES, I.H.; ALVES, S.H.; COSTA, M.M. Atividade antimicrobiana de óleos essenciais de condimentos frente a Staphylococcus spp. Isolados de mastite caprina. Ciência Rural, v.11, p.54-56, 2011.

DALAMARE, A.P.L. et al. Antibacterial activity of the essential oils of Salvia officinalis L. and Salvia triloba L. cultivated in South Brazil. Food Chemistry, v.100, p.603-608, 2007.

DUKE, J.A. Biologically: active compounds important spices. Egypt. Journal Hortic., v.27, n.4, p.459-478, 2002.

ITAKO, A.T.; SCHWAN-ESTRADA, K. Atividade antifúngica e proteção do tomateiro por extratos de plantas medicinais. Tropical Plant Pathology, v.33, p.241-244, 2008.

KUHN, O.J.; PORTZ, R.L.; STANGARLIN, J.R.; DEL ÁGUILA, R.M.; SCHWAN-ESTRADA, K.R.F.; FRANZENER, G. Efeito do extrato aquoso de cúrcuma (Curcuma longa) em Xanthomonas axonopodis pv. manihotis. Ciências Agrárias. v.27, p.13-20, 2006. 
Pansera et al. (2013)

MAYUD, L. et al. Comparision of bacteriostatic and bactericidal activity of 13 essential oils against strains with varying sensitivity to antibiotics. Letters in Applied Microbiology, v.47, p.167-173, 2008.

PEREIRA, R.S. et al. Atividade antibacteriana de óleos essenciais em cepas isoladas de infecção urinária. Revista Saúde Pública, v.38, n.2, p.326-328, 2004.

PEREIRA, M.C.; VILELA, G.R.; COSTA, L.M.A.S.; SILVA, R.F.; FERNANDES, A.F.; FONSECA, E.W.N.; Piccoli, R.H. Inibição do desenvolvimento fúngico através da utilização de óleos essenciais de condimentos. Ciên. Agrotec. v.30, n.4, p. 731-738, 2006.

POVH, J.A.; ONO, E.O. Rendimento de óleo essencial de Salvia officinalis L. sob ação de reguladores vegetais. Acta Sci. Biol. Sci. v.28, n.3, p.189-193, 2006.

RODRIGUES, E.; SCHWAN-ESTRADA, K.R.F.; FIORI-TUTIDA, A.C.; STANGARLIN, J.R.; CRUZ, M.E.S. Fungitoxicidade, atividade elicitora de fitoalexinas e proteção de alface em sistema de cultivo orgânico contra Sclerotinia sclerotiorum pelo extrato de gengibre. Summa Phytopathol., v.33, n.2, p. 124-128, 2007.

ROSAL, L.F.; LEITE, C.D. Eficiência do uso de extrato aquoso de Sálvia em diferentes concentrações sobre o crescimento micelial de Penicillium sp. Rev. Bras. De Agroecologia, v.4, p. 1666-1669, 2009.

SANTOS, A.C.A.; ROSSATO, M., AGOSTINI, F., SERAFINI, L.A., SANTOS, P.L., MOLON, R., DELLACASSA, E., MOYNA, P. Chemical Composition of the Essential Oils from Leaves and Fruits of Schinus molle L and Schinus terebinthifolius Raddi from Southern Brazil. Journal of Essential Oils Bearing Plants, v.12, p.16-25, 2009.

SCHWAN-ESTRADA, K.R.F.; STANGARLIN, J.R.; CRUZ, M.E.S. Uso de plantas medicinais no controle de doenças de plantas. Fitopatologia Brasileira. v.28, p. 554-556, 2003. 